$11-2011$

\title{
Human Rights Law and Military Aid Delivery: A Case Study of the Leahy Law
}

Winifred Tate

Colby College, witate@colby.edu

Follow this and additional works at: https://digitalcommons.colby.edu/faculty_scholarship

Part of the International Relations Commons, Legal Studies Commons, and the Social and Cultural Anthropology Commons

\section{Recommended Citation}

Tate, Winifred, "Human Rights Law and Military Aid Delivery: A Case Study of the Leahy Law" (2011). Faculty Scholarship. 71.

https://digitalcommons.colby.edu/faculty_scholarship/71

This Article is brought to you for free and open access by Digital Commons @ Colby. It has been accepted for inclusion in Faculty Scholarship by an authorized administrator of Digital Commons @ Colby. 


\title{
Human Rights Law and Military Aid Delivery: A Case Study of the Leahy Law
}

PoLAR: Political and Legal Anthropology Review

November 2011

Vol. 34, Number 2, pp 337-354

\begin{abstract}
Explicitly prohibiting US military counternarcotics assistance to foreign military units facing credible allegations of abuses, Leahy Law creation and implementation illuminates the epistemological challenges of knowledge production about violence in the policy process. First passed in 1997, the law emerged from strategic alliances between elite NGO advocates, grassroots activists and critically located Congressional aides in response to the perceived inability of Congress to act on human rights information. I explore the resulting transformation of aid delivery: rather than suspend aid when no "clean" units could be found, US officials convinced their Colombian allies to create new units consisting of vetted soldiers. I use the implementation of the law in Colombia to explore how the vetting process exposed the knowledge practices inherent in policy implementation, the social production of credibility, and ways in which some forms of political violence were made visible while others erased.
\end{abstract}

Key words: human rights, law, policymaking, Colombia, violence 
Human rights activists often turn to the law as a means of enshrining the social changes they seek. Yet the epistemological issues raised by knowledge production and evidentiary standards during policy implementation complicate these processes, leading to unanticipated outcomes. Human rights advocates' efforts to ensure aid was not delivered to abusive military forces though legislation requiring vetting is an important case study of such efforts. The Leahy Amendment to the foreign appropriations bill was first passed in 1997, prohibiting US counternarcotics assistance to foreign military units facing credible allegations of abuses unless the government was taking effective measures to address the allegations. Over the next decade, the amendment was expanded to cover all US military assistance, and was written into permanent law. The law is applied through vetting programs which screen military units for credible allegations of abuses, administered in US embassies abroad. To date, the provision has been applied in high profile cases to freeze assistance to countries including Turkey, Bolivia, Mexico, and Colombia. This case study will address some of the central issues raised by this law. Given the central role of US military assistance in US foreign policy, how did this law come to be passed? What have been the consequences to US military aid delivery? How can we understand the intersection of government action and human rights rhetoric in specific policy processes? What can this case illuminate about the epistemological issues involved in producing knowledge about violence, and attempting to use that knowledge to shape aid delivery? While the creation of the Leahy Law demonstrates what can be achieved through strategic alliances between elite NGO advocates, grassroots activists and critically located Congressional aides, the law's implementation exposes the limits of legal evidentiary standards when applied to military assistance delivery.

Here, I am interested in exploring how domestic law is created and applied transnationally, analyzing the intersection of the growing body of literature considering human rights practice, governance and policymaking. Much of the literature exploring human rights focuses on social movements and non-governmental organizations working across cultural and political fields, examining the multiple ways in which distinct groups localize human rights concerns (Allen forthcoming, England 2006, Goodale 2009, Merry 2006, Merry and Goodale 2007, Speed 2007). Sally Merry, in her pioneering work examining the articulation of legal systems with human rights activism (Merry 2003 a and b, 2006a, b, c and d), has documented how international human rights law can be employed by activists in particular historical moments and political locations to spur transformations in domestic law (Merry 2009). A extensive literature explores human rights mechanisms such as truth commissions and trials adopted during exceptional moments of democratic transition or post conflict accounting (Clarke 2009, Hinton 2010, Shaw and Waldorf 2010, Foss 2002, Theidon forthcoming, Wilson 2001 and 2011), while a small but growing literature examines the ways in which state institutions employing human rights rhetoric and techniques have altered the political terrain of human rights activism (Mertus 2004, Sikkink 2004, Tate 2007). These efforts are embedded in daily state bureaucratic practices (Feldman 2008, Anders 2010), and as such are subject to the policymaking process shaping institutional mandates and frameworks. These policymaking processes are themselves increasingly become objects of ethnographic study (Greenhalgh 2008, Mosse 2004, Wedel, Shore, Feldman and Lathrop 2005). This article builds on the central insights from the anthropology of policy, including the 
multiple ways in which policy creation and implementation remain embedded in fraught political fields that both respond to and produce cultural norms, procedures and practices, as well as the insights from truth commission scholarship and the anthropology of human rights that insists on the limitations of legal processes and evidentiary requirements for articulating accountability in cases of state-sanctioned violence.

Colombia is a particularly useful place to consider the implementation of the Leahy Law for several reasons. The activists who were instrumental in the initial passage of the law were focused on human rights abuses by Colombian military units receiving US assistance. The law was passed as the U.S. prepared to begin a massive influx of military assistance to Colombia, which totaled approximately $\$ 5.2$ billion dollars from 2000 to 2009 as part of Plan Colombia. Efforts to apply the law in Colombia have resulted in the largest vetting program of any embassy in the world. At the same time, shifting military strategy and forms of political violence complicated efforts to implement the law.

This essay is part of a larger project examining the origin and impact of Plan Colombia involving fieldwork in Washington, Miami, Putumayo, and Bogota. I have employed diverse research methods in response to my limited access to policymaking practices. As a Visiting Research Fellow at the National Security Archives, I analyzed embassy cables and government documents gained through Freedom of Information Act requests, the majority of which are highly redacted; many remain unreleased. I interviewed policymakers involved in the Plan Colombia Interagency Task Force, State and Defense Department officials, members of Congress and their staff, Embassy personnel, current and retired military officers, and activists. Many of the individuals requested anonymity, in some cases because they are still employed within government bureaucracies. I have honored such requests, indicating civilian (noted as "officials") or military (noted as "officers") status, and the institution where employed (State, Defense, Congress). I am also drawing on notes, contacts and analysis from my experience as a participant in these debates. From 1998-2001, I was the Colombia analyst at the Washington Office on Latin America, a progressive advocacy organization that opposed the military assistance component of the package. This case study, like many efforts to produce ethnographies of policymaking processes, demonstrates the need to employ multiple methodologies while emerging from an existing embeddedness in the process being analyzed (Greenhalgh 2008, Mosse 2004; see Tate 2007:13-20 for a discussion of embeddedness).

\section{Creation of the Leahy Law as Policy Assemblage}

While the Leahy Law bears the name of the Senate's primary spokesman for human rights concerns, Vermont Senator (D) Patrick Leahy, the law was the product of a complex field of alliances between Washington-based human rights advocates, grassroots activists, and supportive Congressional staff. The necessary policy assemblage, defined as "the collection of heterogeneous, often incommensurate elements that come together for a period of time, sometimes quite fleeting, to produce a policy construct" (Greenhalgh, 2008:13), included the conflux of these actors, as well as the human rights reporting produced by Amnesty and other human rights non-governmental organizations, the legislative process mastered by critically positioned aides, and the post-cold war 
moment of NGO professionalization and growing acceptance of human rights rhetoric among foreign policy institutions.

The decision of human rights groups to attempt to intervene directly in the policymaking process must be understood in the context of post-cold war, pre-war on terror expansion of the increase in rhetorical commitment by governmental agencies to human rights agendas. At the same time, Latin America was widely viewed as a continent characterized by transitions to democracy, and the human rights community was focused on issues elsewhere, including the Balkans and Africa (Mertus 2004, Sikkink 2004). This period was also characterized by increasing professionalization of human rights groups, many of which emerged as NGOs with paid staff trained in human rights law, many focusing on advocacy within the policymaking process, rather than as volunteer appendages to social movements. These groups ranged from small organizations with between 5 and 15 paid staff to transnational institutions with multimillion dollar budgets; while some like Human Rights Watch focused on reporting the majority made an effort to link their work with grassroots volunteer activists. Despite efforts by these NGOs to promote expanded grassroots mobilization on Colombia, such activism was extremely limited when compared to the broad movement against US military aid to Central America two decades prior (Smith 1996). US domestic drug war politics as well as the lack of a political solidarity with the Colombians guerrilla movements contributed to the reluctance of many activists to get involved. The United States did not have as many as direct connections with Colombia; there was not a significant refugee population, nor were many of the religious, academic and volunteer ties between the two countries as had existed with Central America and served as the foundation for activist connections decades previous (Tate 2009).

Amnesty International advocates developed a new strategy focused on producing legislation that would target aid to specific units because of their frustration with the inability to implement earlier broader human rights legislation. The first generation of explicitly human rights focused legislation was passed in the 1970s; these laws mandated a complete cut-off of aid if abuses occurred and were never enforced. When Pentagon representatives and other supporters of military aid argued that cutting off all military aid to a country because of specific abuses carried out by particular units was unfairly punishing an entire institution "for the work of a few bad apples, we decided to turn the argument on its head, and go after the few bad apples," according to Carlos Salinas, then Latin America advocacy director. ${ }^{1}$ They capitalized on their human rights reporting to raise awareness of the issue, including a 1994 study of abuses by the Colombian military and national police, many of which were receiving US counternarcotics assistance. AI Washington-based advocates mobilized their grassroots membership in specific Congressional districts, particularly those represented by a cohort of Republican selfproclaimed "drug warriors" in an effort to counterbalance their commitment to funding militarized counternarcotics programs. Senator Leahy also worked to assuage politicians concerns about the impact of the legislation, including sending letters to National Security Advisor Sandy Berger and Representatives Hastert and Gilman, assuring them that the law would not be used to improperly withhold aid. ${ }^{2}$ 
The original amendment was developed in close collaboration between Congressional staff and Amnesty International staff, buttressed by the critically positioned long-time AI supporter Tim Rieser. The language was written by a Senate staffer, passed to AI for revisions, and circulated to Rieser. ${ }^{3}$ As senior staff for Patrick Leahy, the ranking Democrat on the Senate Appropriations Committee, Rieser was able to place the language in the bill without open debate on the floor. According to one former Congressional aide involved in the process, "The amendment itself was not publicly debated, but inserted into the bill during conference, the closed door negotiations to reconcile House and Senate versions of legislation. There were a lot of people who would have fought it, if they had known about it, but Tim put it through quietly, under the radar." 4

\section{Transnational Agreements}

As a new requirement for the delivery of foreign assistance, the Leahy Amendment (and later law) involved intense negotiation with foreign governmental agencies to establish formal agreements with each foreign government stipulating how they would meet the requirements of the Leahy Law, called end use monitoring. Many officials involved viewed human rights concerns within the context of their domestic interagency power disputes, as well as manifestation of ongoing neo-colonial US-Latin American relations characterized by the unilateral imposition of human rights standards the US government failed uphold in its own policies (Mertus 2004). Efforts to negotiate an agreement that would satisfy all parties demonstrated the distinct political agendas between and among US and Colombian government agencies, and revealed the weakness of Colombian civilian power structures in the face of military institutions. These negotiations also demonstrated significant disagreement over the policy process among US officials, some of whom objected to the imposition of such requirements on an ally. In one of the most notorious examples, declassified embassy cables revealed that during a May 1997 trip to Colombia, Speaker of the House Dennis Hastert told Colombian military officers he would work to "remove conditions on assistance" and complained about the previous years of "leftist" influence in the U.S. Congress that "used human rights as an excuse to aid the left in other countries." Hastert promised to promote counternarcotics assistance and recommended that Colombian officials should "bypass the U.S. executive branch and communicate directly with Congress." 5 Throughout these debates, the amount of US assistance was never in doubt, only the recipient. During tense moments of standoff between US and Colombian officials, the US never threatened to reduce assistance, merely to shift the aid from one institution (the military) to another (the police).

The debates over the Colombian military's acceptance of the Leahy provisions must be understood in the context of their broader objections to civilian oversight by Colombian government agencies, including the delegitimized president, as well as their view that the

United States was displaying both hypocrisy and left-wing bias in their demands. ${ }^{6}$ Efforts to finalize the end-use monitoring agreement occurred during the worst modern crisis of US-Colombian relations. The US revoked President Ernesto Samper's visa and decertified Colombia following revelations (publicly released by the US Drug Enforcement Administration) that he had accepted campaign contributions from the Cali 
Cartel. ${ }^{7}$ Colombian military officers, long accustomed to significant administrative independence, chaffed under what they perceived as civilian corruption (Aviles 2006). US assistance at the time was concentrated on the Colombian National Police, which enjoyed a stellar reputation among their Congressional Republican supporters, in large part due to the charismatic leadership of General Jose Rosso Serrano (Crandall 2002). The military, in turn, felt marginalized from the exclusively counternarcotics-focused assistance packages, and maligned by accusations of corruption and incompetence from many US counterparts. Despite a history of close US-Colombia military relations dating from the Korean War (Coleman 2008), Colombian military officers generally viewed human rights concerns as politically motivated slander, even coming from US officials (Tate 2007).

The Leahy Law required a new process certifying that no credible allegations existed for each unit. Previously, the US had accepted a biyearly "good faith certification" from the Colombians, simply stating that they met all the US requirements for legal transfer. ${ }^{8}$ One of the major points of contention remained the issue of what to do with accused individuals while they awaited the outcome of their case, and concern that the Leahy provisions would increase the number of accusations against the Colombian security forces. ${ }^{9}$ On April 30, the embassy reported that an end use monitoring agreement had been signed for the 506 and 614 assistance with the Colombian Air Force and Navy, but that the Army refused. Negotiations over the end use monitoring agreement came to a head during frustrated talks during the summer of 1997 as Colombian Army lawyers argued that any sanction (including removal from US-supported units) required a "completed judicial process." ${ }^{10}$ Army Commander General Harold Bedoya complained of State Department bias against the Colombian army. The cable reporting on one of the many meetings in which the end-use monitoring requirements were discussed concluded by recommending sending "all equipment possible originally destined for the armed forces to the police." ${ }^{11}$ At this point, events were transformed by the internal dynamics of Colombian politics. Bedoya was forced to resign after a showdown with the president over proposed negotiations with the guerrillas in July 1997. His replacement, General Jose Bonnett, signed the end-use monitoring agreement on July 30, 1997.

\section{Limits of the legal}

The Leahy Law is implemented by embassy personnel charged with vetting proposed soldiers and units by checking their names against available records, including a human rights database maintained by the Embassy containing information from Colombian government agencies such as the federal prosecuting agencies, NGO reports, and media accounts. According to US Embassy officials, the Colombia vetting program is the largest in the world. More than 30,000 names have been vetted; for comparison, the vetting program in Saudi Arabia has processed approximately 300 names. ${ }^{12}$ According to embassy officials interviewed in 2008 , the Colombia program goes "above and beyond the law," including vetting civilians and contractors in order to prevent training or assistance going to retired military personnel with outstanding complaints against them. Officials note, however, that the embassy cannot prevent training from being provided. 
Rather, they issue their judgment, and then "the marines have ten days to tell congress to go to congress to explain why they went ahead with the training." 13

What constitutes a military "unit" has been fiercely debated. The idea of a military "unit" is not easily transferrable into the logic of accountability that the authors of the Leahy Law attempted to establish. Military personnel are organized into a range of military "units," including patrol, platoon, company, battalion, brigade, division, ranging in size from 6-10 people to thousands. These units are administrative fictions, set in a permanent hierarchy and relatively stable organizational structure but with their membership in constant flux. Through the rotation of personnel, injuries, and command promotions the specific individuals within the structure vary widely and are difficult to trace. These administrative divisions are used as the receptacles for assistance, equipment and training, as well as operational deployment, with missions assigned to particular divisions by geographic location. Critics of the Leahy provision used this administrative instability to argue against the vetting process, or as evidence that the Leahy language was inadequate, urging institutional reform be the prerequisite for eligibility for US funding and support. The State Department settled on vetting the smallest "unit" possible. According to a 1999 General Accounting Office (GAO) report, "in a May 8, 1999 cable to all overseas embassies, the State Department defined the unit to be trained as the unit to be vetted. Thus, for individual training, the individual will be vetted. For unit-level training, the unit itself will be vetted" (53). According to this interpretation, individual soldiers from abusive units can participate in training as long as they are not linked by name to a credible allegation (Amnesty International and the Fellowship of Reconciliation 2008:7-8).

The majority of allegations entering the vetting process in Colombia originate from NGOs and investigations conducted by Colombian law enforcement agencies, thus suffering from all the institutional limitations and weaknesses that have been well documented in the Colombian legal system (Human Rights Watch 2002, Tate 2007). US embassy personnel are incapable of conducting independent verification of allegations, because of lack of personnel, investigative training and lack of mandate in foreign countries. Centralized information management systems do not exist, making following cases extremely difficult. ${ }^{14}$ In addition, some governmental institutions have resisted the vetting process, particularly military forces. ${ }^{15}$

Assessing what constitutes credible allegations is one of the thorniest issues in Leahy implementation. The vetting process is one of many where human rights advocates face escalating demands for institutional transparency and the production of evidence meeting legal standards, including identifiable and credible witnesses and supporting documentation and expert knowledge about weaponry, troop movements and identities, all extremely difficult to procure in complex conflict situations. Anthropologists and others have explored the ways in which "credibility" as an epistemological category is culturally produced, and how the measures of violence is itself a contested process (Andreas and Greenhill 2010; Comaroff and Comaroff 2006; Rosa and Satterthwaite 2009). Anthropologists examining the role of truth commissions have explored the multiple ways in which public accusations of wrongdoing are socially produced, 
including the critical space of silences (Ross 2010), the gendered dimensions of such pronouncements (Theidon 2010) and the role of post-conflict fear shaping public discourses about histories of violence. In this case, credibility functions as a kind of social capital that is achieved through specific kinds of knowledge practices or accrued through institutional positioning. Some NGOs are known to have more sophisticated, standardized and rigorous reporting practices, and are thus more credible than other NGOs. To the US government, Colombian government agencies are considered inherently more credible than NGOs, with governmental reporting and judicial investigations - and dismissal of such investigations - weighted more heavily than NGO reporting. Of the NGOs, hierarchies of credibility include national groups over regional, professional over volunteer, international over national (Tate 2007). These hierarchies of credibility also apply among and within governmental agencies. US governmental agencies are more credible than Colombian agencies; for officials from both governments, human rights focused agencies (such as the Bureau of Democracy, Human Rights and Labor, DRL, in the State Department and the Colombian Human Rights Ombudsman) are less credible than other agencies. ${ }^{16}$

Different bureaus within the State Department, and different agencies within the US government, have different assessments of the human rights performance of the Colombian military. In one case, US officials praised a Colombian military regional commander as "tough, disciplined...more in the mold of US counterparts." ${ }^{17}$ Five months later, US embassy officials "strongly opposed" his appointment as head of Colombian joint military intelligence, given "numerous" credible links between the officer and paramilitary groups, making him "wholly unsuitable for this highly sensitive position." 18 Some government officials explained the Colombian government's removal of particular officers for human rights abuses as the result of political infighting rather than evidence of abuses. Within the State Department, these divisions are often expressed as conflicts between the regional bureaus (in this case, the Western Hemisphere bureau and the Colombia desk, and the thematic bureau of DRL). For example, one Foreign Service officer told me, "DRL sees their constituency as US NGOs, they have a specific audience in mind." He said that many US officials viewed them as "in their own little world." 19 Another former Congressional staffer recalled that "part of it comes down to who is a better judge of what is credible, DRL or the other bureaus. If it is a local NGO, the regional bureaus may try to argue that they are in a better place to know if the allegation is credible or not." ${ }^{20}$ Similarly, in Bogota interviews during the early years of Plan Colombia, journalists covering Colombia said US officials visiting Colombia left markedly different messages on human rights for the Colombian officials they met with. "A CODEL [Congressional delegation] comes down and tells the military, don't do this. Then the Pentagon comes down and says, we love what you are doing," one senior reporter for a major US news daily said. ${ }^{21}$ These differences are central in the application of the Leahy Law, depending on which agency makes the final call on the status of particular units. In particularly controversial cases, the final decision is sent from the Embassy to higher-ranking bureaucrats in Washington. ${ }^{22}$

An additional controversy over Leahy implementation involved the issue of what constituted "effective measures" taken by the state to address the credible allegations. 
While the activists involved in the creation of Leahy imagined that effective measures would necessarily involve the investigation and prosecution of accused officers, implementation of the law has not led to any such efforts. During the initial conversations between US and Colombian officials over implementation, their reluctance to involve the legal system was made clear. One example was a 1998 conversation with the US ambassador, Colombian Minister of Defense Rodrigo Lloreda concluded that "a culture of impunity prevails in Colombia," calling the civilian judicial system "woefully ineffective" as well as expressing "a lack of confidence in the military judiciary." He "discounted the likelihood of improving the current situation in the short term for cultural reasons," including the fact that many think long-term incarceration for any crime seems "unfair.", ${ }^{23}$ In some of the cables describing the vetting process, embassy officials appear to endorse the view that simply preventing tainted soldiers from participating in US-supported units is sufficient. One April 1999 cable suggests that simply preventing soldiers with accusations of violations from being rotated into these units is sufficient to meet the "effective measures" standard established by the Leahy Law. ${ }^{24}$ The 1999 GAO report described the Defense Department's policy guidance as considering "adjusting the planned activity or participants" to be the required "corrective action to address situations where there is credible information of gross human rights violations by a member of a unit" (55). Rather than insisting that investigations led to a trial, the individual is simply removed for the duration of the training. Embassy personnel have stated in interviews that the Leahy vetting process has resulted in senior officials being forced out of the military because they could not get training required for promotion and arrests. Certainly there is considerable diplomatic pressure brought to bear on specific cases of military officers linked to human rights abuses. However, the specific link between this pressure and efforts to fulfill the Leahy requirements is not clear. There is no public record available documenting such cases, and no evidence of systematic pressure brought to bear on follow-up in the cases of individuals found to have credible allegations against them.

The focus on implementation overlooks broader issues in vetting of soldiers as a framework for conditioning aid. The focus on individuals within units erases the ways in which military equipment - and training - is fungible, as people and goods circulates freely within military networks. Any aid sent to military institutions benefits the entire force, as it frees resources for reassignment, including to abusive units. Anyone trained benefits the entire military institution, as there is no tracking of location or performance post-training, so that individuals can return to abusive units, or be transferred into abusive units, and use their improved skills to bad ends. Much of US assistance is nonmaterial, in forms that cannot be restricted, such as knowledge and intelligence, which circulates freely throughout the units, vetted and unvetted alike. By focusing on individual military perpetrators, the vetting process also ignores the military logics of command responsibility, an established legal tenant that holds officers responsible for crimes committed by troops under their command. In the history of cases of soldiers legally tried for atrocities, very few are higher ranking officers. The stress on individual responsibility also erases the role of economic and political structural relationships in generating political violence. Many police officers, retired military officers and government prosecutors stressed in conversation that the strength of criminal networks in certain 
areas, such as Medellin, made not participating in corruption and political violence extremely difficult. ${ }^{25}$

The vetting process is also not responsive to shifts in the forms and practices of violence in Colombia. During this period, many analysts observed what some called the privatization of political violence, as human rights groups tracked a decline in the direct participation of military forces in abuses while the number of such attacks attributed to paramilitary forces rose dramatically (Tate 2010). ${ }^{26}$ Military supporters, including within the US military and the Clinton administration, claimed that the reduction in direct military attribution of abuses was the result of genuine reform within the military. Critics pointed to the evidence of collaboration between military and paramilitary forces, arguing that the military had not reformed but had replaced direct action with collusion.

Paramilitary forces also resorted to new modalities of violence, apparently designed to allow perpetrators to escape the scrutiny of international human rights reporting. Paramilitary documents circulating on the internet began discussing the need to obey human rights standards, and their webpage links to pages of communiqués on human rights issues from paramilitary "political advisors;" small town officials told me of hearing from paramilitary commanders that they had learned to avoid human rights scrutiny by not committing massacres. Instead, paramilitary groups killed their targets one by one, scattering the bodies in different places or holding the bodies for several days, now called "multiple homicides" by human rights groups. ${ }^{27}$ Such incidents are not tracked by international organizations that focus on massacres as a significant human rights indicator. Similarly, as internal forced displacement attracted the intention of a number of international organizations, paramilitary forces began a new practice of refusing to let rural inhabitants leave their communities, called "confinement" but much more difficult to document in remote regions (U.S. Office on Colombia 2005). Some emerging forms of violence are particularly difficult to link to individual soldiers or even particular units, such as the practice of "false positives," in which young men are disappeared from their homes and presented in distant states as guerrillas killed in combat (Haugaard and Nichols 2010).

The Leahy Law places the burden of proof on victims of violations to recognize and name members of particular units involved in the atrocities committed against them. Eyewitnesses often cannot distinguish individual soldiers by name, because of the military's institutional emphasis on uniformity. Human rights reporting rarely identifies soldiers individually, instead focusing on military operations in the areas where abuses occur. These factors are issues in all efforts to use legal standards as a basis for establishing human rights-based criteria, and point to the larger epistemological challenges of translating human rights knowledge production into particular policies.

\section{Leahy Implementation and the New Military Strategy}

The Leahy end-use monitoring agreement set the stage for a major increase in US assistance to the Colombian military, starting with a new military to military cooperation agreement signed in December 1998 prior to the massive influx of aid through the Plan Colombia package in 2000. Part of this expanded military cooperation included the 
creation of a series of US-trained and equipped counternarcotics battalions of the Colombian army. US officials soon realized that given the widespread allegations of military misconduct, it was practically impossible to find Colombian military units that could pass the Leahy vetting requirements. Faced with the difficulty of vetting existing units, US officials and their Colombian counterparts soon developed a new military strategy that would resolve the vetting problems through the creation of new, 'clean' units. Made up of vetted individuals, these units would be eligible for all US assistance and training, because as new units with no existing record, they would be instantly cleared.

In March 1998, the first unit to be vetted and cleared for US assistance was the Eastern Specified Command (CEO), and it proved an inspiration for the creation of new units. As noted in a March 1998 cable to Washington, the unit "didn't really exist": as a unified military command converted into an army command in 1996 for "contingencies in the border area," the command does not actually exist as a fully constituted military unit, but has only a "minimal number of full time troops;" instead, "battalions from other units are 'op-conned' to the CEO." 28 While the CEO was recommended for immediate aid, the vetting process exposed "problems" - credible allegations of abuses committed by all the other units proposed for US assistance. ${ }^{29}$

By October, the proposal to create a new, clean counternarcotics battalion was supported by the Colombian military and executive. According to a 1998 embassy cable, the "unit to be designated would probably be relatively new and 'clean' of significant human rights problems." The Colombians viewed this as a concession to US pressure, asking "in return" for US funding for equipment; military officers also reported "understanding" that making such units focused on counternarcotics would "maximize ready access to US intelligence." 30 The issue of Leahy and vetting lead the embassy to propose "starting out with 'clean' units." In order ensure that they are legally able to deliver military aid, the embassy described their plan to discuss "possibility of standing up 'clean' new units comprised of pre-screened troops," with the Ministry of Defense, concluding that "in the context of a major boost in designated assistance (eg counternarcotics battalion) the colar [Colombian Army] might be willing to consider such a move." A cable dated the next day describing a meeting between the US ambassador and the Colombian Minister of Defense reported that after pointing out problems with existing units proposed for US assistance, the US ambassador told the Minister of Defense, that in order to facilitate supplying aid, the Ambassador proposed, "the raising of 'new' units made up of prescreened troops untainted by human rights abuses." 31

Policymakers involved in the design of the Plan Colombia package emphasized the importance of creating new units that could receive the massive influx of assistance. According to Ambassador James Mack, the coordinator of the Plan Colombia InterAgency Task Force, "the vetting was probably one of the reasons that we decided to start all over again, from scratch, with a new unit. We wanted to train them up to US standards." Similarly, officials with the US Southern Command reported that the Leahy requirements were "why we did not use an existing battalion." 
We went down there, with Special Forces trainers, and figured out how to make things work with the State Department vetting. We made sure that none were from other units, that they were individuals that were new to the military, that they were brand new with no possibilities of problems. ${ }^{32}$

Maintaining the artificial separation between new "clean" and existing abusive units proved difficult on the ground, particularly given the US focus on improved military operational integration and coordination. The new clean counternarcotics units operated in joint campaigns with local units, including those facing allegations of abuse, such as the $24^{\text {th }}$ Brigade in Putumayo, part of the US' "Push into Southern Colombia" strategy. While the $24^{\text {th }}$ had been decertified for aid, the brigade continued to work in concert with the expanding military presence in the region. Among the talking points for the ambassador was the fact that "the participation of the 24th Brigade is critical for counternarcotics operations and the success of Plan Colombia," but that "persistent reports that the 24th Brigade, and the 31 st Counterguerrilla Battalion in particular, has been cooperating with illegal paramilitary groups that have been increasingly active in Putumayo." ${ }^{33}$ During the time period that these cables were sent, the human rights situation in the region was described as extremely serious by a number of human rights organizations. Human Rights Watch devoted a chapter to the $24^{\text {th }}$ brigade in their report, The Sixth Division: Military-paramilitary Ties and US Policy in Colombia. The title referred to allegations that paramilitary forces in Colombia operated as a "sixth division" of the Army, which was divided into five regional commands. In the report, Human Rights Watch wrote of the relationship between paramilitaries and military forces in Putumayo from 1999-2001, concluding that "the Twenty-Fourth Brigade maintained a close alliance with the paramilitaries, resulting in extrajudicial executions, forced disappearances, and death threats" (Human Rights Watch 2001:16). Similarly, the Office of the United Nations High Commissioner for Human Rights in Colombia presented repeated reports to the Colombian government of links between paramilitary and military forces in the Putumayo region during this time period, to no effect (United Nations High Commissioner for Human Rights 2001).

\section{Conclusion: Implementation of the Law and the Silencing of Policy Debates}

In assessing the consequences for US military aid delivery, the views of the activists focused on the issue are divided. Congressional aides who supported the law claim it sent the message that "human rights is important to the US Congress." They used other political mechanisms, such as the confirmation process for ambassadors, to bring pressure to ensure compliance. One supporter explained the law is a tool for allies in the State Department... It gets the lawyers in the room for the discussions of US policy, because a bureaucracy wants to argue to provide aid as a matter of policy. In Leahy, there is no waiver, no balancing test. So in this kind of bureaucratic context, you can't do any better to empower a weak bureaucrat than to say, to deliver aid in this condition is illegal. ${ }^{34}$

However, other human rights advocates point out the degree to which the focus on Leahy has shifted the terms of the debate and political action to efforts to support and assess 
Leahy implementation itself rather than articulate and organize against inhumane or unjust policies. Vetting practices reflect the legal focus on individual responsibility, but silence larger debates over the causes and consequences of political violence. According to Lisa Haugaard of the Latin America Working Group, a coalition of human rights NGOs and humanitarian agencies that focus in part on Colombia, "You can get lost in the technicalities of the Leahy Law." She argued that "The less technical something is, the more useful it can be in terms of policy." ${ }^{35}$ The human rights debate over the Leahy Law becomes focused on providing documentation for implementation, rather than pushing for more systemic reforms, arguing that the military assistance itself is not the best means to achieving stated US policy goals, or critiquing broader capitalist and imperial systems. Some groups, particularly those located outside of Washington and functioning as grassroots membership organizations, focused on opposing all military aid to Colombia, finding the focus on implementing conditions such as the Leahy law a divisive distraction.

The creation of human rights law does not simply involve translation, in which the aspirations of activists are translated into the idiom of legislation. Law opens up space for new bureaucratic practices as institutional players promote distinct political projects while employing the same rhetoric of rights. An ethnographic approach illuminates such efforts by tracking human rights rhetoric and practice across these multiple contested political fields, in legislative forums and in implementation. In this case, bureaucratic practices of implementation opened space for powerful institutions, such as the U.S. military and the State Department, to impose their interpretation of specific elements of the legislation, including what constitutes a unit, a credible allegation or an effective measure to address an allegation of abuse. These debates over vetting practices demonstrate the distinct political projects in play as some institutions focused on avenues to maximize military aid in the face of activists' insistence that human rights safeguards should prevail.

This analysis of the Leahy Law reveals the multiple ways in which the implementation as well as the creation of the law is embedded in particular historical and political processes. Shaped by the transnational diplomatic context of a growing US military presence in Colombia, the law shifted US policy, but not in the ways that the activists and policymakers who designed the law originally intended. Rather than suspend aid when no "clean" units could be found, US officials convinced their Colombian allies to create new units consisting of vetted soldiers, and did not implement a wider push for the investigation and trial of accused officers as part of the law's mandate despite clear language in the law requiring "effective measures" following abuses. Debates over how to construct the vetting process itself exposed the knowledge practices inherent in law enforcement, the social production of credibility, and ways in which some forms of political violence were made visible while others erased. As government action increasingly intersects with and employs the rhetoric of human rights, tracking the multiple state effects of such practices is critical for understanding the political terrain of human rights.

\footnotetext{
Notes

${ }^{1}$ Author interview, Washington, July 1, 2008.
} 
${ }^{2}$ Author interview, Washington, January 8, 2008.

${ }^{3}$ Author interview, Washington, January 23, 2006.

${ }^{4}$ Author interview, Washington, October 14, 2008.

${ }^{5}$ U.S. Embassy Colombia cable, "CODEL [Congressional Delegation] Hastert's May 2427 Visit to Colombia," May 28, 1997, Secret, 28 pp.

${ }^{6} 19970616$ - Cable, "Ambassador's June 13 Conversation with Defmin Echeverri”" [Folder: Sec asst.] State Department Embassy Cable 05740, “Ambassador's June 13 converation with defmin echeverri," 16 June 1997. confidential.

${ }^{7}$ US Congress requires the State Department to issue a yearly certification of foreign governments, assessing their degree of cooperation with US counternarcotics operations. Failure to be certified results in the suspension of non-military aid, in addition to other sanctions.

${ }^{8} 19970428$ - Bogota cable, "506 and 614: Best and Final Offer to MOD” [Sec asst] 919970429 - Bogota Cable, “Ambassador's April 28 Meeting with President Samper" [EUM].

1019970708 - Bogota cable, "Bedoya Lawyer Blocks EUM Accord” [EUM] State Department Embassy Cable 06461, "Bedoya Lawyers blocks EUM accord," 8 July 1997. Confidential.

${ }^{11}$ State Department Embassy Cable 006705, "EUM talks with Defmin at Dead End; Recommendation," July 14, 1997. confidential.

12 Author interviews, Bogota, June 4, 2008.

13 Author interviews, Bogota, June 4, 2008.

${ }^{14}$ Colombian legal institutions have made significant advances in important human rights investigations. However, these legal cases have rarely resulted in completed trials and sentencing, and these institutions follow a pattern of initial success in investigating human rights cases followed by institutional weakening; however, they have contributed to the US-maintained database for vetting purposes.

${ }^{15}$ In the initial efforts for the Colombia certification, the Colombian Ministry of Defense failed to provide appropriate information. (State Department Embassy Cable 00272, "Colombian EUM Update: Embassy Lights a Fire Under MOD," 15 January 1998.

Confidential.) Subsequent cables reported that the issues had been resolved ("For Ambassador meeting with Minister Lloreda Drafter WSRowland,” 04/22/99. confidential).

${ }^{16}$ Author interviews, Bogota, 2008.

${ }^{17}$ State Department Embassy Cable 1998 [excised] "[excised] hr visit to colar second division and $5^{\text {th }}$ brigade in Bucaramanga - a tough region with lots of bad guys of all types," June 11, 1998.

${ }^{18}$ State Department Embassy Cable, "Demarche Request on Appointment of Brigadier General Luis Fernando Millan As Head of Joint Military Intelligence,” November 25, 1998. Confidential.

${ }^{19}$ Author interview, Bogota, June 4, 2008.

${ }^{20}$ Author interview, Washington, January 23, 2006.

${ }^{21}$ Author interview, Bogota, March 12, 2003.

${ }^{22}$ Some cables describing the implementation process offer different views of the unit, concluding that "we leave it to Washington." State Department Embassy Cable 002520, 
"Colombia EUM: Analysis of Specific Human Rights Cases," 6 March 1998.

Confidential.

${ }^{23}$ State Department Embassy Cable 011674, “Ambassador and Minister Lloreda on Leahy Amendment," 16 October 1998, Confidential.

${ }^{24}$ For Ambassador meeting with Minister Lloreda Drafter WSRowland 04/22/99. Confidential.

${ }^{25}$ Author interviews, Bogota, 1998-2004.

${ }^{26}$ Prior to the mid-1990s, the Colombian security forces were generally considered to be the worst perpetrator of abuses, with approximately $55-60 \%$ of abuses catalogued by NGOs attributed to the military and the police; by the end of the 1990s the percentage had fallen to less than $4 \%$, with the majority of such violence attributed to paramilitary forces (Comisión Colombiana de Juristas, 2005). For more on the political debates surrounding these statistics, see Sanchez 2001 and Tate 2007.

${ }^{27}$ Author interviews, Bogota, 2005.

${ }^{28}$ State Department Embassy Cable 002520, "Colombia EUM: Analysis of Specific Human Rights Cases," 6 march 1998. Confidential.

29 "Colombia EUM: Analysis of Specific Human Rights Cases," 6 march 1998. Confidential.

${ }^{30}$ State Department Embassy Cable 11602, "Colombian Army Counter-Narcotics Battalion Proposed for USG Assistance," 15 October 1998, Confidential.

${ }^{31}$ State Department Embassy Cable 011674, "Ambassador and Minister Lloreda on Leahy Amendment," 16 October 1998, Confidential.

${ }^{32}$ Author interview, Miami, January 11, 2009.

${ }^{33} 2000$ July 05 U.S. State Department, cable, "Approach to MOD [Minister of Defense] on 24th Brigade."

${ }^{34}$ Author interview, Washington, January 23, 2006.

${ }^{35}$ Author interview, Washington, July 3, 2008.

\section{References}

Allen, Lori.

Forthcoming Human Rights and the Palestinian Project.

Amnesty International and the Fellowship of Reconciliation

2008 Assisting Units That Commit Extrajudicial Killings: A Call to Investigate U.S. Military Policy Towards Colombia, Washington. Washington: Amnesty International and the Fellowship of Reconciliation. http://www.amnesty.org/en/library/asset/AMR23/016/2008/en/116d47ce-236b$11 \mathrm{dd}-89 \mathrm{c} 0-51 \mathrm{e} 35 \mathrm{dab} 761 \mathrm{~d} / \mathrm{amr} 230162008$ eng.html

Anders, Gerhard. 2009 In the Shadow of Good Governance: An Ethnography of Civil Service Reform in Africa. London: Brill Academic Publishers.

Andreas, Peter, et al.

1996 Drug War Politics. Berkeley: University of California Press. Andreas, Peter, and Kelly M. Greenhill, eds. 
2010 Sex, Drugs and Body Counts: The Politics of Numbers in Global Crime and Conflict. Ithaca: Cornell University Press.

Aviles, William

2006 Global Capitalism, Democracy, and Civil-military Relations in Colombia. New York: SUNY Press.

Clarke, Kamari Maxine 2009 Fictions of Justice: The International Criminal Court and the Challenge of Legal Pluralism in Sub-Saharan Africa. Cambridge: Cambridge University Press.

Coleman, Bradley 2008 Colombia and the United States: The Making of an Inter-American Alliance, 1939-1960. Kent: Kent State University Press.

Comisión Colombiana de Juristas. 2005 El deber de la memoria: Informe sobre el año 2004. Bogotá: Comisión Colombiana de Juristas.

Comaroff, Jean, and John L. Comaroff 2006 Figuring Crime: Quantifacts and the Production of the Un/Real. Public Culture 18(1):209-246.

Coxshall, Wendy 2005 From the Peruvian reconciliation commission to ethnography: narratives, relatedness and silence. PoLAR: Political and Legal Anthropology Review 28(2):203-23.

Crandall, Russell 2002 Driven By Drugs. New York: Lynne Rienner.

Englund, Hari 2006 Prisoners of Freedom: Human Rights and the African Poor. Berkeley: University of California Press.

Feldman, Ilana. 2008 Governing Gaza: Bureaucracy, Authority, and the Work of Rule, 19171967. Durham: Duke University Press.

General Accounting Office 1999 Military Training: Management and Oversight of Joint Combined Exchange Training, document number GAO/NSIAD-99-173, Washington, DC: GAO.

Goodale, Mark 2009 Human Rights: An Anthropological Reader. Malden, MA: WileyBlackwell.

Goodale, Mark, and Sally Engle Merry 2007 The Practice of Human Rights: Tracking Law Between the Global and the Local. Cambridge: Cambridge University Press.

Greenhalgh, Susan 2008 Just One Child: Science and Policy in Deng's China. Berkeley: University of California Press.

Haugaard, Lisa and Kelly Nichols

2010 Breaking Silence: In Search of Colombia's Disappeared, Washington,

D.C.: Latin America Working Group and the U.S. Office on Colombia.

High Commissioner for Human Rights 
2001 Report of the U.N. High Commissioner for Human Rights on the human rights situation in Colombia, E/CN.4/2001/15, February 8, 2001.

Hinton, Alexander Laban, editor

2010 Transitional Justice: Global Mechanisms and Local Realities after

Genocide and Mass Violence. Newark: Rutgers University Press.

Human Rights Watch

2002 The Wrong Turn: The Wrong Turn: The Record of the Colombian Attorney General's Office. New York: Human Rights Watch.

----- 2001 The Sixth Division: Military-Paramilitary Ties and U.S. Policy in Colombia. New York: Human Rights Watch.

Merry, Sally

2006a Anthropology and International Law. Annual Review of Anthropology 35(1):99-116.

----- 2006b New Legal Realism and the Ethnography of Transnational Law. Law \& Social Inquiry 31(4):975-995.

----- 2006c Transnational Human Rights and Local Activism: Mapping the Middle. American Anthropologist 108(1):38-51.

----- 2003a Rights Talk and the Experience of Justice. Human Rights Quarterly.

----- 2003b Constructing a Global Law-Violence against Women and the Human Rights System. Law \& Social Inquiry 28(4):941-977.

------ 2006d Human Rights and Gender Violence: Translating International Law into Local Justice. Chicago: University of Chicago Press.

Merry, Sally Engle, et al.

2009 Law From Below: Women's Human Rights and Social Movements in New York City in Law \& Society Review 44(1):101-128.

Merry, Sally, and Mark Goodale, eds.

2007 The Practice of Human Rights: Tracking Between the Local and the Global. Cambridge: Cambridge University Press.

Mertus, Julie

2004. Bait and Switch: Human Rights and U.S. Foreign Policy. New York:

Routledge.

Mosse, David

2004 Cultivating Development: An Ethnography of Aid Policy and Practice.

New York: Pluto Press.

Rosga, AnnJanette, and Margaret Satterthwaite

2009 The Trust in Indicators: Measuring Human Rights, in the Berkeley Journal of International Law, 27(2):253-315.

Ross, Fiona

2010 An Acknowledged Failure: Women, Voice, Violence and the South African Truth Commission. In Rosalind Shaw and Lars Waldorf editors, Localizing Transitional Justice: Interventions and Priorities after Mass Violence. Palo Alto: Stanford University Press.

----- 2002 Bearing Witness: Women and the Truth and Reconciliation Commission. London: Pluto Press.

Sanchez, Gonzalo 
2001 Introduction in Charles Bergquist, Ricardo Penaranda and Gonzalo Sanchez, Violence in Colombia, 1990-2000: Waging War and Negotiating Peace. New York: Scholastic Resources Books.

Shaw, Rosalind and Lars Waldorf, editors

2010 Localizing Transitional Justice: Interventions and Priorities after Mass

Violence. Palo Alto: Stanford University Press.

Sikkink, Kathryn

2004 Mixed Signals: U.S. Human Rights Policy and Latin America. Ithaca: Cornell University Press.

Smith, Christian

1996 Resisting Reagan: The Central American Peace Movement. Chicago: University of Chicago Press.

Speed, Shannon 2007 Rights in Rebellion: Indigenous Struggle and Human Rights in Chiapas. Palo Alto: Stanford University Press.

Tate, Winifred

2010 Accounting for Absence: The Colombian Paramilitaries in U.S. Policy Debates. In The Politics of Numbers, Peter Andreas and Kelly Greenhill, eds. Ithaca: Cornell University Press.

----- 2009 Human Rights NGOs and the U.S. debate over Plan Colombia. Colombia Internacional, 69, ene - jun 2009, Pp. 50 - 69.

----- 2007 Counting the Dead: The Culture and Politics of Human Rights Activism in Colombia. Berkeley: University Of California Press.

Theidon, Kimberly forthcoming Intimate Enemies: The Politics of Truth and Reconciliation in Peru. Palo Alto: Stanford University Press.

U.S. Office on Colombia 2005 Tools of the Colombian Conflict: Civilian Confinement and Displacement, Washington: U.S. Office on Colombia.

Wedel, Janine R., et al.

2005 Toward an Anthropology of Public Policy. The ANNALS of the American Academy of Political and Social Science July (600):30-51.

Wilson, Richard. 2011 Writing History in International Criminal Trials. Cambridge: Cambridge University Press.

----- 2001 The Politics of Truth and Reconciliation in South Africa: Legitimizing the Post-Apartheid State. Cambridge: Cambridge University Press. 